\title{
The Application of Flipped Class Model in College English Teaching of Polytechnic Schools
}

\author{
Lei Ding \\ Applied Foreign Language Department \\ Jilin Communications Polytechnic Institute \\ Changchun, China
}

\begin{abstract}
Current English classes of Polytechnic schools remain little time for the students to study and think by themselves. It is necessary to explore a new teaching model to better improve students' practical English abilities. Flipped class model and "micro-class" have been widely applied in western countries. The emerging of these new teaching styles transfuses something valuable to English class innovation in China beyond all questions. Aiming at popularizing flipped class model in college English teaching, this thesis falls into five parts: the introduction of current college English teaching conditions, the elaboration of flipped class model, flipped class model applied to college English course, the feasibility of flipped class model applying to college English teaching and a conclusion.
\end{abstract}

Keywords-flipped class model; micro-class; college English teaching; application; feasibility

\section{INTRODUCTION}

With the development of economy and technology, more and more job positions require high-quality college graduates. Facing a large group of job hunters, the students' English listening and speaking abilities would be a competitive quality to a great extent. However, the current situation unfortunately goes to another extreme. An increasing number of polytechnic school graduates are extremely poor at their English which in turn leads to their lack of interests in learning English. Realizing this serious and important problem, Chinese Education Department began to focus on improving students' English speaking abilities. The outline for college English precisely indicates that the object for college English is to cultivate students' comprehensive abilities including their listening and speaking abilities, reading ability, writing ability and translating ability. Among which the English listening and speaking abilities are stressed. College English teaching should enable the students to communicate for information in their future positions and social occasions. In traditional English classes, teachers spend long time explaining grammar and language points. The time remaining for students to practice their oral English is far less than enough. It is necessary to explore a new teaching model to better improve students' practical English abilities. With painstaking efforts, flipped class model is proved to be an effective means to improve college students' oral English abilities.

\section{FLIPPED CLASS MODEL}

\section{A. The Definition of Flipped Class Model}

Salman Khan put forward a new teaching modelflipped class model, also named an inverted class-room in America in 2011. The original idea is to transform the traditional style of learning in class and practicing out of class to a new model of learning out of class and practicing in class. The emerging of this style transfuses something new to English class innovation beyond all questions. In this model, the roles of teachers and students changed dramatically and the bad effects brought by the traditional teacher-centered class model can be totally avoided. By this inverted style, the students inquire knowledge out of classroom through micro-class videos provided by the teachers. Their classrooms become a platform for students and teachers to discuss problems and communicate for new information. The core of this model is to provide a new style of "learning first out of class, practicing second in class".

\section{B. Characteristics Of Flipped Class Model}

1) The changes of teacher's role: Firstly, the traditional role of teachers in class is a dominator who controls the whole class. In such a class, the students can only be controlled and passively get information. In the flipped class, the students being a main body of the class is realized to a large extent. At the same time, the teacher's role as an instructor is enhanced rather than weakened. The teachers should be able to flexibly use a variety of teaching methods as task-based teaching, problem-based teaching and role play etc. In this sense, the teachers become a guider designing tasks for the students rather than an imparter passing on knowledge. Secondly, the teachers are no longer standing on the stage speaking and writing on the blackboard. Instead, they upload their teaching videos on the Web for the students to download or watch online so as to learn knowledge by themselves out of class. In this sense, teachers become a teaching resources provider.

2) The changes of student's role: With some high technologies such as Internet and multimedia equipments applying in the education field, the students have more choices of where to learn, what to learn, how to learn and 
how much to learn. They become an active learner rather than a passive receiver. Besides, they can choose either to learn by themselves or to learn with his or her groups out of the class. In class, the students work in groups to share their problems and figure out the answers together.Through discussion they may exchange ideas with each other and sometimes they can find something new which are ignored by the teacher. Instead of being a knowledge consumer, the students become a knowledge producer in some degree.

3) Re-distribution of class time: The traditional English class is a 45-minute period with 30 minutes for the teachers to impart knowledge and 15 minutes remaining for the students to do the exercises and oral practice. By studying out of class with videos, the students may have more time in class to discuss with the teacher on those difficult points and practice with the fellow students. The teachers may also design more interactive activities for the class such as learning experiences sharing, task fulfilling and role playing etc. In a word, the time remaining for the students in class is increasing.

\section{FliPPED Class MOdEl APPliEd TO COLlEGE ENGLISH COURSE}

In considering of the current situations of polytechnic school students, the application of flipped class model in college English course contains three necessary procedures: knowledge imparting out of class, interactive activities in class and evaluation process. The students' characteristics should be taken into consideration in each respective procedure.

\section{A. Knowledge Imparting out of Class}

Knowledge imparting procedure enables the students to inquire language points necessary for them. Knowledge imparting largely depends on the videos produced by teachers which is also named as a micro-class. Mini-class is realized through the platform of a series of teaching videos in which the teachers prepare the studying points including some important and difficult points and their explanations. It is an online video course supporting various learning methods. According to the "Basic Requirements of English Curriculums for Polytechnic Schools" launched by the Education Department in October, 2000, teachers may have a long list of language points at hand. The teachers may produce their teaching videos according to the knowledge points listing on the "Basic Requirements". A special attention should be paid to the sequences of knowledge points from simple to complicate step by step. While preparing the videos, teachers should keep an eye on the following suggestions.

1) Short and elaborate videos: Firstly, comparing with the traditional teaching courseware packaged in the optical disks, micro-class is welcomed by both teachers and students for its elaborate qualities and plentiful resources. Since the students are not willing to stay long on a specific language point, the micro-class usually lasts no longer than 10 minutes. Secondly, as a foreign language, English teaching should focus more on developing the students' language intuition. College English for polytechnic school students is comparatively easier than English for the 4-year university schools. The passages seldom contain those long and complicated sentences. Instead, the topics in the texts all relate to current affairs which easily draw students' attentions. Therefore, when preparing the videos, teachers may search some relative videos, animations, images and audio resources from the Internet which will in turn arouse the students' interests in learning English. Meanwhile, the students' listening abilities may be enhanced greatly.

2) Videos focusing on the studying points: The teachers may add some pictures and animations to the videos. However, too much decoration may also attract students' attentions. Sometimes even a teacher with a new dressing will catch students' attentions. Thus, it is highly suggested that teachers do not appear in the video. It's enough to provide your audio explanations and PPT. Whatever your style is, always bear in your mind that the focus of your video is to impart knowledge. Besides, your video should highlight the important points and difficult points.

3) Videos suitable for the students: While preparing for the videos, teachers should make an investigation on the students' English levels. Students of polytechnic schools are poor at vocabulary and grammars. Besides, their selfstudying ability needs to be improved. Based on the students' knowledge frame and studying ability, the teachers should make a list of the knowledge points from simple to complex. In designing the videos, it's necessary for the teachers to combine simple tasks with complex language points artificially to enable the students remind something they have learnt while facing something new. In a word, learning through the video is a process of reviewing something old and previewing something new.

\section{B. Interactive Activities in Class}

After studying by themselves, students come to the class with questions respectively. However, it's unnecessary to explain every question of each student. It's the teacher who should select some valuable topics for the students to discuss. The topics chosen should either help the students to solve their problems or arouse their interests in learning new knowledge. Variety of interactive activities may easily draw the students' attentions.

1) Group discussion: The students are divided into several groups with a leader gathering their discussion results. They discuss the topics chosen by the teacher until a conclusion is arrived. During this process, they may solve the problems they had met in the self-studying process with the help of their group members. Sometimes they come to a new question to share with students in other groups and the teacher. After their discussion, each group makes a presentation on the problems they have solved and the problems they have encountered. The new problems can either be solved with the help of other groups or the teacher. 
The group discussion process helps the students to inquire knowledge through brainstorming.

2) Developing students' abilities of solving problems alone: Through my own observations on polytechnic school students, a chief reason why they are not interested in studying English is largely due to the traditional teaching model with the teacher being in the center ignoring students' reactions. By flipping the class to a new style with students being in the center, the students are more willingly to solve problems and exploring new knowledge by themselves rather than passively inquiring knowledge taught by the teacher. By constantly applying this model, the students may form a good habit of solving problems by themselves.

3) Respecting each student's specialties: Each student has his or her own specialties respectively. On one hand, the teacher should make sure that every student is approaching to the learning objectives. On the other hand, each student's special qualities should be respected. For example, Mary is good at writing and Jack may fluently talk in English. A good teacher should be good at exploring each student's good qualities and make them enhanced through your class.

4) Videos remaining a thinking space for the students: As an explorer in the field of flipped class model, you'd better realize the importance of leaving a space for the students to think while watching the videos. Thus, a good video provider won't put an end to his or her videos. On the contrary, a new problem may jump out to the students for them to figure out the answers. By leaving something to the students, the teachers may contribute to help the students form a good habit of thinking alone.

\section{Evaluating Process}

Currently, the students' English learning results largely depend on their final exams. It's improper to judge a student's performance in class by a final score. An extensive evaluation system on the students' daily performance is eager for exploring.

1) Focusing on the evaluation of process: In the flipped class model, the evaluating process should highly take the students' daily performance and their achievements in class into consideration. The aspects of evaluation should include the students' feedbacks after watching the videos, the devotions he or she has made in the topic discussion process and the fulfillment of his or her assignments.

2) Variety of evaluation: It's unreasonable to evaluate students' performance only by one teacher. In other words, the evaluation system can be varied. First of all, teachers are still in charge of the students' final score. However, the students' daily performance should be considered. The teachers can also invite other teachers to join in the evaluating process. Secondly, the fellow students can also take part in the evaluating procedure to evaluate the performances and devotions of his or her fellows. Thirdly, the model of the final exams can be diverse. Writing a paper or a thesis, giving a speech, making a group discussion, holding a debate, or doing a role play are various forms for the students to choose by themselves. By reforming the evaluation system, the students completely change their roles as being passive receivers to active learners.

\section{The FEASIBILITy OF FLIPPED Class Model APPLYING TO COLLEGE ENGLISH TEACHING}

As a newly developed teaching model, flipped class needs to be examined by practices. Whether it is a practical model for college English teaching or not also needs to be verified. The author makes an investigation on whether the flipped class model is available for college English or not from aspects as following.

\section{A. An Analysis on College Teachers}

First of all, the groups of college teachers tend to be younger and younger these years with higher degree. On the one hand, young teachers have a strong desire to accept new things and put new technologies into practice. On the other hand, most of the young college teachers were born after 1980s. They are influenced by the traditional teachercentered class model deeply. Therefore, young teachers are willing to carry some new teaching models forward including the flipped class model.

Secondly, by doing a research on the teachers from some polytechnic schools, the author comes to a conclusion that a large amount of teachers believe in their innovating abilities. They have faith in advancing teaching reforms in spite of obstacles. Some teachers have already taken part in the teaching innovations. This proves that a majority of young college teachers with rich language teaching experiences and a complete knowledge frame are able to realize some innovative teaching models. These excellent human resources may contribute a lot to the developing of microclass videos and the experiments of flipped class model.

Last but not least, college English teachers have a good ability in using high technologies as computers and softwares. These abilities provide a foundation for teachers to develop high-quality PPTs and elaborate micro-class videos. A master of information technologies by the teachers is a necessary condition to carry out college English innovations.

\section{B. An Analysis on Polytechnic School Students}

1) Self-studying ability: Compare with high school students, college students have enhanced self-controlling abilities. Campus is a place to develop students' selfdeveloping abilities. Without the care of their parents, without the supervision of teachers, college students quickly form a habit of depending on their own. A research on the self-studying ability of 100 students from JiLin Communications Polytechnic Institute shows that $8.3 \%$ of the total amount believe that they have a strong selfstudying ability. They can independently fulfill the previewing tasks and assignments without teachers' supervisions. Another $20.8 \%$ of the students say they are good at studying by themselves. Most of the students are 
willing to study by themselves in a relatively quite environment without interruption. Only a few students of about $9.2 \%$ are unwilling to either learn by themselves or study with the help of teachers and fellow students. The numbers above demonstrate that a majority of college students have the ability to study by themselves and some have strong self-studying ability.

2) Class communication ablitity: Another research made among the same group of students shows that $63.2 \%$ of the students are good at communicating with their fellow students in English in class including $28.3 \%$ who are excellent in speaking English fluently. Only a small group of students have no faith in discussing with their classmates in English in class.

The above researches demonstrate that polytechnic school students have the ability of studying by themselves out of class and discussing certain topics with their fellow students in class. As the beneficiaries of teaching reform, the students are also important participators and executors. In current situations, the students are able to participate in the flipped class.

\section{An Analysis on the Teaching Environment}

1) Current situations: Compared with the traditional teacher-centered teaching model, the English classes nowadays have changed dramatically. Some teachers have already made some innovations in their classes. First of all, multimedia equipments have been adopted in English classes. Teachers no longer talk through the whole class boringly. During the class, the students may watch some videos, animations and colorful pictures relating to the topics. Secondly, teachers who are good at information technology develop PPT for the class in their spare time. The explanations are showed on the screen with clear procedures and attractive pictures, even with animations. Thirdly, teaching researches provide teachers with a platform for sharing their teaching experiences and innovations. However, the attempts made by teachers are far less than enough. The pictures, videos, audios and animations can draw the students' attention only for a while. When coming back to the key points, the students may show their careless again. After class, some students only remember the interesting pictures and videos rather than the language points. Besides, by showing the language points on the screen in class, the students don't get enough time to think independently and find their own problems and ways to solve them. In most occasions, the students are exposed to several knowledge points, but only a few are acquired by them.

2) Hardware equipments: With the development of technology and economy, the fund devoted to education is increasing gradually. Each classroom is equipped with devices as computer, screen and other multimedia devices. Besides, the students can study in electronic library with public computers provided by schools. These equipments provide students a good condition to learn online.

\section{CONCLUSION}

The coming of high-tech era brings both chances and challenges for college English teaching. English teachers of polytechnic schools should take advantages of those high technologies and applied them into practical teaching process. Flipped class model is an adventurous experiment of combining new technologies with class teaching together. By adopting the flipped class model and micro-class videos in college English teaching, the students can successfully change their roles from a passive receiver to an active learner. However, as a new teaching model, flipped class model needs to be explored and improved constantly.

\section{ACKNOWLEDGMENT}

I would like to express my gratitude to all those who helped me during the writing of this thesis. I gratefully acknowledge the help of my supervisor, who has offered me valuable suggestions in the academic studies. In preparing this thesis, he spent much time reading through each draft and provided me with inspiring advice. Without his patient instruction, insightful criticisms and expert guidance, the completion of this thesis would not have been possible.

I also owe a special debt of gratitude to all my colleagues in Foreign Language Institute, from whose devoted teaching and enlightening lectures I have benefited a lot and academically prepared for the thesis.

Lately my thanks would go to my beloved family for their loving considerations and great confidence in me all through these years. I also owe my sincere gratitude to my friends and students who gave me their hell and time in listening to me and helping me work out my problems during the difficult course of the thesis.

\section{REFERENCES}

[1] Abeysekera, Lakmal, and Phillip Dawson (2015). "Motivation and cognitive load in the flipped classroom: definition, rationale and a call for research." Higher Education Research \& Development 34(1), 1-14.

[2] Ryback, D., \& Sanders, J. (1980). Humanistic versus traditional teaching styles and student satisfaction. Journal of Humanistic Psychology, 20(87), 87-90.

[3] Marco Ronchetti (June 2010), "Using video lectures to make teaching more interactive", International Journal of Emerging Technologies in Learning (iJET)

[4] Sparks, S. D. (2011). Schools "flip" for lesson model promoted by Khan Academy. Education Week, 31(5), 1.

[5] Alvarez, B. (2011). Flipping the classroom: Homework in class, lessons at home. Education Digest: Essential Readings Condensed For Quick Review, 77(8), 18-21.

[6] Maureen Lage, Glenn Platt, Michael Treglia (2000), Inverting the Classroom: A gateway to Creating an Inclusive Learning Environment, Journal of Economic Education.

[7] Lents, N., \& Cifuentes, O. (2009). Web-based learning enhancements Video lectures through voice-over PowerPoint in a Majors-level Biology course. Journal of College Science Teaching, 39(2), 38-46.

[8] Strayer, J. F. (2012). How learning in an inverted classroom influences cooperation, innovation and task orientation. Learning Environments Research, 15(2), 171-193.

[9] Bennett, B., Spencer, D., Bergmann, J., Cockrum, T., Musallam, R., Sams, A., Fisch, K., \& Overmyer, J. (2013). The flipped classroom manifest. 